\title{
KEPASTIAN HUKUM PEMENUHAN UPAH KARYAWAN DALAM PEMBAGIAN HARTA PAILIT
}

\author{
EMPLOYEE'S LEGAL WAGE ASSURANCE COMPLIANCE OF \\ BANKRUPTCY ALLOCATION ASSETS
}

\author{
Mochamad Rifki Hidayat \\ Fakultas Hukum Universitas Brawijaya \\ Email : advokat.rifkihidayat@gmail.com
}

\begin{abstract}
The bankruptcy state of a corporation should have been obtained to determine the precise action to preserve from the liquidation process. This research will study a case sample from PT. Kertas Leces to analyze and examine the employee's legal wage assurance compliance of bankruptcy allocation assets as justified on the Constitutional Court verdict number 67/PUU-XI/2013 in order to disclose and assign the order of debtor's bankruptcy assets distribution in valid regulations and law accordance. The researcher used Juridical-Normative method and carried out a normative approach to develop this study which contains of statutory approach. The researcher used the approaches to analyze the regulations and the Constitutional Court verdict number 67/PUU-XI/2013, and other regulations related to this research. This study concludes that a legal policy should be represented toward fundamental and ethical values. In addition, neither of the laws can obstruct an individual's rights to entirely receive without a conditional exception. According to the written definition, labors are not paid for the classification as a creditor, yet they deserve the wages for the professions they are conducting. The term matter presents that labors or employee should have been prioritized in the bankruptcy assets allocation as well as exclude them from creditor status.
\end{abstract}

\section{Keywords : Legal Wage; Assurrance Compliance; Bankruptcy Assets}

\begin{abstract}
Abstrak
Dalam proses terjadinya kepailitan suatu perusahaan patut diketahui, karena hal ini dapat menentukan keberlanjutan tindakan yang dapat dilakukan pada perseroan yang telah dinyatakan pailit. Sebagai contoh adalah PT. Kertas Leces. Tujuan dari penelitian hukum ini adalah untuk menganalisis dan mengkaji kepastian hukum pemenuhan upah pekerja dalam pembagian harta pailit ditinjau dari putusan Mahkamah Konstitusi Nomor 67/PUU-XI/2013 guna menemukan dan menentukan tata urutan pembagian harta pailit debitur sesuai dengan ketentuan hukum yang berlaku. Metode penelitian yang digunakan yaitu Yuridis-Normatif dan pendekatan yang dilakukan dalam merumuskan penelitian ini adalah pendekatan normatif yang didalam pendekatan normatif terdapat Pendekatan perundang-undangan, pendekatan ini digunakan dalam hal meneliti dan menganalisis undang-undang, dalam hal ini penulis menggunakannya untuk menganalisa Putusan Mahkamah Konstitusi Nomor : 67/PUU-XI/2013, maupun undang-undang lain yang berkaitan dengan penelitian ini. Hasil kajian ini menyimpulkan bahwa suatu aturan hukum harus bercermin terhadap suatu prinsip dan nilai-nilai etis, tidak dapat suatu aturan hukum menghalang-halangi hak seseorang dapatkan untuk mendapatkan dengan utuh dan tanpa pengecualian. Pada sejatinya buruh adalah orang yang dibayar karena suatu pekerjaan yang dilakukannya, bukan diklasifikasikan sebagai seorang
\end{abstract}


kreditur, maka sepatutnyalah apabila buruh didahulukan dalam pembagian harta pailit dan mengecualikan dari status kreditur.

\section{Kata kunci : Kepastian Hukum; Pemenuhan Upah; Harta Pailit}

\section{PENDAHULUAN}

Perkembangan perekonomian global membawa pengaruh besar terhadap perkembangan hukum ekonomi di Indonesia. Globalisasi hukum akan menyebabkan peraturan-peraturan negara berkembang mengenai investasi, perdagangan, jasa-jasa dan bidang perekonomian lainnya mendekati negara-negara maju. Dalam rangka menyesuaikan dengan perekonomian global, Indonesia melakukan revisi terhadap seluruh hukum ekonominya.

Keberadaan Badan Usaha Milik Negara (BUMN) bertujuan untuk menyelenggarakan kemanfaatan umum berupa penyediaan barang dan jasa bagi pemenuhan hajat hidup rakyat guna mewujudkan kesejahteraan masyarakat yang merata. Hal ini berarti Badan Usaha Milik Negara (BUMN) harus mampu memberikan manfaat kepada rakyat. Pada kenyataannya Badan Usaha Milik Negara (BUMN) seringkali tidak memperoleh keuntungan, justru mendatangkan kerugian. Terlebih lagi pemerintah sebagai pemegang saham harus menanggung kerugian yang di alami oleh Badan Usaha Milik Negara (BUMN). ${ }^{1}$ Kerugian tersebut dapat berakhir pailit atau likuidasi, kepailitan dapat terjadi karena makin pesatnya perkembangan perekonomian dan perdagangan dimana muncul berbagai macam permasalahan utang-piutang yang timbul dalam masyarakat, hal tersebut sangatlah wajar apabila melihat iklim ekonomi Indonesia sedang dalam masa berkembang.

Pailit dalam kamus hukum ekonomi di artikan sebagai kegiatan pemberesan harta pailit milik perusahaan yang di ikuti dengan proses penjualan harta perusahaan, penagihan piutang, pelunasan utang kepada para kreditur, serta penyelesaian sisa harta atau utang antara pemegang saham. Berdasarkan pasal 1 angka 1 Undang-Undang Nomor 37 Tahun 2004 tentang Kepailitan dan Penundaan Kewajiban Pembayaran Utang (PKPU) berbunyi:

"Kepailitan adalah sita umum atas semua kekayaan debitor pailit yang pengurusan dan pemberesannya dilakukan oleh kurator di bawah pengawasan hakim sebagaimana diatur dalam undang-undang ini".

Proses terjadinya kepailitan sangatlah perlu diketahui, karena hal ini dapat menentukan keberlanjutan tindakan yang dapat dilakukan pada perseroan yang telah dinyatakan pailit. Sebagai contoh penulis adalah PT. Kertas Leces sebagaimana putusan majelis hakim No. 01/Pdt.Sus, Pembatalan Perdamaian/2018/PN. Niaga. Sby Jo. Perkara No. 5/Pdt. Sus PKPU/2014/PN.Niaga.Sby Jo. Perkara No. 43PK/Pdt.SusPailit/2019. Hal ini yang menjadikan sebuah permasalahan hukum selanjutnya hingga pada saat ini

${ }^{1}$ Rahayu Hartini, 2017 "BUMN PERSERO, Konsep Keuangan Negara dan Hukum Kepailitan Di Indonesia", Setara Press, Malang, , hal 36. 
belum menemui titik terang mengenai rincian daftar pembagian tersebut yang dilakukan oleh Tim Kurator di Media Massa (Koran Nasional dan Lokal) yakni pada tanggal 30 April 2019. Hal ini karena masing-masing kreditur menyatakan hak tagihannya harus di dahulukan dalam pembagian harta pailit, bahwa salah satu pasal dalam Undang-Undang Nomor 13 Tahun 2003 tentang Ketenagakerjaan yaitu Pasal 95 ayat (4) menyatakan :

"Dalam hal perusahaan dinyatakan pailit atau dilikuidasi berdasarkan peraturan perundang-undangan yang berlaku, maka upah dan hak-hak lainnya dari pekerja/buruh merupakan utang yang didahulukan pembayarannya".

Akan tetapi dalam perkara PT. Kertas Leces tersebut mantan buruh ditempatkan dalam posisi setelah pemenuhan hak negara dan para kreditor separatis, menimbulkan adanya ketidakpastian hukum apabila mengacu Putusan Mahkamah Konstitusi Nomor 67/PUU-XI/2013 yang amarnya sebagai berikut :

"Pasal 95 ayat (4) Undang-Undang Nomor 13 Tahun 2003 tentang Ketenagakerjaan (Lembaran Negara Republik Indonesia Tahun 2003 Nomor 39, Tambahan Lembaran Negara Republik Indonesia Nomor 4279) bertentangan dengan Undang-Undang Dasar Negara Republik Indonesia Tahun 1945 sepanjang tidak dimaknai: "pembayaran upah pekerja/buruh yang terhutang didahulukan atas semua jenis kreditur termasuk atas tagihan kreditur separatis, tagihan hak negara, kantor lelang, dan badan umum yang dibentuk Pemerintah, sedangkan pembayaran hak-hak pekerja/buruh lainnya didahulukan atas semua tagihan termasuk tagihan hak negara, kantor lelang, dan badan umum yang dibentuk Pemerintah, kecuali tagihan dari kreditur separatis".

Ketidakpastian hukum tersebut adalah wujud inkonsistensi terhadap putusan majelis hakim Mahkamah Konstitusi yang bersifat final dan mengikat dalam hal urutan pembagian harta pailit. Pada praktik hukum dilapangan seringkali terjadi penyimpanganpenyimpangan atau bahkan benturan antar norma hukum, hal itu terjadi karena norma hukum yang mengatur tentang tata urutan pembagian harta pailit masih bias. Sehingga menurut hemat penulis perlu dan patut untuk dilakukan kajian dan analisa hukum. Penulis juga menemukan terdapat beberapa kerancuan peraturan perundang-undangan yang mengatur tata urutan pembagian harta pailit terhadap klasifikasi kreditur, baik Preferen, Separatis maupun Konkuren, karena Kreditur Preferen mempunyai hak istimewa untuk didahulukan pembayaraan karena undang-undang, sedangkan Kreditur Separatis mempunyai hak juga menurut undang-undang untuk didahulukan karena memegang hak jaminan yang dapat sewaktu-waktu melakukan parate eksekusi. Lantas yang menjadi focus kajian dan analisa hukum penulis adalah apakah upah buruh masuk dalam klasifikasi Kreditur Preferen (namun harus didahulukan daripada hak Negara), atau Kreditur Separatis (yang memegang hak jaminan) atau kreditur lainnya, karena apabila masuk dalam kategori Kreditur Preferen mana yang harus didahulukan, upah buruh atau pajak?, mengingat Putusan Mahkamah Konstitusi Nomor 67/PUUXI/2013 yang pada pokoknya menyatakan pembayaran upah buruh didahulukan daripada kreditur lainnya, namun para kreditur lain seperti separatis dan preferen juga 
menyatakan haknya harus didahulukan karena mempunyai Hak untuk mendahului sebagaimana di atur dalam undang-undang Perpajakan, Jaminan Kebendaan, Fidusia, dan Hak Tanggungan.

Di dalam Undang-Undang Nomor 37 Tahun 2004 tentang Kepailitan dan Penundaan Kewajiban Pembayaran Utang tidak tegas mengatur tentang tata urutan pemabagian harta pailit, menurut hemat penulis tidak dapat putusan Mahkamah Konstitusi Nomor 67/ PUU-XI/2013 serta-merta dapat membatalkan ketentuan undang-undang Perpajakan, Jaminan Kebendaan, Fidusia, dan Hak Tanggungan. Yang harus di uji materi adalah Undang-Undang Nomor 37 Tahun 2004 tentang Kepailitan dan Penundaan Kewajiban Pembayaran Utang, karena merupakan Lex Specialis yang mengatur tentang kepailitan, kalau hanya yang di uji adalah materi undang-undang Ketenegakerjaan, lantas bagaimanakah undang-undang Perpajakan dan Kepailitan menentukan Haknyalah yang harus didahulukan daripada buruh, padahal didalam putusan Mahkamah Konstitusi Nomor 67/PUU-XI/2013 sudah sangatlah jelas, terlebih lagi didalam pasal 95 undangundang nomor 11 tahun 2020 tentang Ciptakerja juga sudah jelas mengatur.

Beberapa penelitian telah mengkaji tentang hukum kepailitan diantaranya tentang hukum kepailitan dalam eksekusi harta benda korporasi sebagai pembayaran uang pengganti ${ }^{2}$. Kemudian penelitian dengan kepailitan pengembang rumah susun ${ }^{3}$, perlindungan hukum bagi kreditor terhadap pelunasan hutang dari harta pailit ${ }^{4}$, dan perlindungan hukum kreditor dari undang-undang kepailitan ${ }^{5}$. Berdasarkan literatur tersebut belum ada yang meneliti tentang kepastian hukum pemenuhan upah buruh dalam pembagian harta pailit. Berdasarkan latar belakang dan tinjauan literatur sebelumnya maka rumusan masalah dalam penelitian ini adalah bagaimanakah kepastian hukum pemenuhan upah buruh dalam pembagian harta pailit ditinjau dari putusan putusan Mahkamah Konstitusi Nomor : 67/PUU-XI/2013?

\section{PEMBAHASAN}

\section{Putusan Mahkamah Konstitusi 67/PUU-XI/2013 Dalam Kepailitan}

Putusan Mahkamah Konstitusi (MK) merupakan putusan yang tidak hanya mengikat para pihak (inter parties) tetapi juga harus ditaati oleh siapapun (erga omnes). Asas erga omes tercermin dari ketentuan yang menyatakan bahwa putusan MK langsung dapat dilaksanakan dengan tidak memerlukan lagi keputusan pejabat yang berwenang kecuali peraturan perundang-undangan mengatur lain. Ketentuan tersebut merefleksikan

\footnotetext{
${ }^{2}$ Lambok Marisi Jakobus Sidabutar, 2015, Hukum Kepailitan dalam Eksekusi Harta Benda Korporasi sebagai Pembayaran Uang Pengganti, hlm 78, Jurnal Antikorupsi INTEGRITAS, 5 (2), 75-86 e-ISSN/p-ISSN: 2615-7977/2477$118 \mathrm{X}$.

${ }^{3}$ Imanuel Rahmani, Perlindungan Hukum Kepada Pembeli Dalam Kepailitan Pengembang (Developer) Rumah Susun, 2018, hlm 80, Jurnal Hukum Bisnis Bonum Commune, Volume I, Nomor 1.

${ }^{4}$ Hamdi, Sulaiman, Teuku Yudi Afrizal, Perlindungan Hukum Bagi Kreditor Terhadap Pelunasan Piutang Dari Harta Pailit, 2020, hlm 23, Jurnal Ilmiah Mahasiswa, Volume 1 Nomor 1.

${ }^{5}$ Dedi Tri Hartono, Perlindungan Hukum Kreditor Berdasarkan Undang-Undang Kepailitan, 2016, hlm 6, Jurnal Ilmu Hukum Legal Opinion, Edisi I, Volume 4.
} 
kekuatan hukum mengikat dan karena sifat hukumnya secara publik maka berlaku pada siapa saja, tidak hanya berlaku bagi para pihak yang berperkara. Asas putusan MK berkekuatan hukum tetap dan bersifat final sebagaimana disebutkan dalam pasal 10 ayat (1) berikut penjelasan Undang-Undang Nomor 8 Tahun 2011 tentang Perubahan Undang-Undang Nomor 24 Tahun 2003.

Namun dalam pelaksanaannya, putusan MK memiliki berbagai macam permasalahan dalam implementasinya. Salah satunya adalah putusan MK Nomor : 67/PUU-XI/2013 tentang pengujian Pasal 95 ayat (4) Undang-Undang Nomor 13 Tahun 2003 tentang Ketenagakerjaan. Bahwa dalam pasal Pasal 95 ayat (4) Undang-Undang Nomor 13 Tahun 2003 tentang Ketenagakerjaan tersebut upah buruh harus di dahulukan daripada kreditur lainnya, bunyinya sebagai berikut:

"Dalam hal perusahaan dinyatakan pailit atau dilikuidasi berdasarkan peraturan perundang-undangan yang berlaku, maka upah dan hak-hak lainnya dari pekerja/buruh merupakan utang yang didahulukan pembayarannya".

Pada tahun 2013 para Pekerja Pertamina mengajukan permohonan Pengujian Undang-Undang Nomor 13 Tahun 2003 tentang Ketenagakerjaan terhadap UndangUndang Dasar Negara Republik Indonesia Tahun 1945, berdasarkan Akta Penerimaan Berkas Permohonan Nomor : 305/PAN.MK/2013 dan telah dicatat dalam Buku Registrasi Perkara Konstitusi pada tanggal 27 Juni 2013 dengan Nomor : 67/PUU$\mathrm{XI} / 2013$. Dalam permohonnannya tersebut, para pemohon secara konstitusional berdasarkan Pancasila dan Undang-Undang Dasar Negara Republik Indonesia Tahun 1945 menyatakan bahwa dalam pelaksanaan pembangunan nasional, tenaga kerja mempunyai peranan yang penting sebagai pelaku dan tujuan pembangunan dalam rangka untuk pembangunan manusia Indonesia yang seutuhnya dan pembangunan masyarakat Indonesia seluruhnya untuk mewujudkan masyarakat yang sejahtera, adil, dan makmur. Perlindungan terhadap tenaga kerja merupakan perlu dan penting untuk menjamin kesamaan kesempatan serta perlakuan tanpa diskriminasi atas dasar apapun untuk mewujudkan kesejahteraan pekerja/buruh dan keluarganya.

Pasal 28D Undang-Undang Dasar 1945 menyatakan bahwa setiap orang berhak untuk mendapatkan imbalan dan perlakuan yang adil dan layak dalam hubungan kerja. Negara Kesatuan Republik Indonesia menjamin, melindungi serta memenuhi hak-hak warga negaranya melalui konstitusinya yaitu Undang-Undang Dasar 1945. Beberapa diantaranya adalah hak atas kepastian hukum dan hak atas perlindungan yang layak dalam hubungan kerja, sebagaimana diatur dalam Pasal 28 ayat (1) dan ayat (2) Undang-Undang Dasar 1945 yang berbunyi sebagai berikut: (1) Setiap orang berhak atas pengakuan, jaminan, perlindungan, dan kepastian hukum yang adil serta perlakuan yang sama dihadapan hukum. (2) Setiap orang berhak untuk bekerja serta mendapat imbalan dan perlakuan yang adil dan layak dalam hubungan kerja". 
Untuk melaksanakan mandat konstitusi tentang hak atas pekerjaan sebagaimana dinyatakan dalam Pasal 28 ayat (1) dan ayat (2) Undang- Undang Dasar 1945, maka pada tanggal 25 Maret 2003 Pemerintah Republik Indonesia, pada masa pemerintahan Presiden Megawati Soekarno Putri telah mengeluarkan dan mengesahkan UndangUndang Nomor 13 Tahun 2003 tentang Ketenagakerjaan. Bahwa tujuan dari di undangkannya Undang-Undang Nomor 13 Tahun 2003 tentang Ketenagakerjaan adalah sebagaimana disebut dalam pertimbangannya, yaitu:

a. Bahwa pembangunan nasional dilaksanakan dalam rangka pembangunan manusia Indonesia seutuhnya dan pembangunan masyarakat Indonesia seluruhnya untuk mewujudkan masyarakat yang sejahtera, adil, makmur, yang merata, baik materiil maupun spiritual berdasarkan Pancasila dan Undang-Undang Dasar Negara Republik Indonesia Tahun 1945;

b. Bahwa dalam pelaksanaan pembangunan nasional, tenaga kerja mempunyai peranan dan kedudukan yang sangat penting sebagai pelaku dan tujuan pembangunan;

c. Bahwa sesuai dengan peranan dan kedudukan tenaga kerja, diperlukan pembangunan ketenagakerjaan untuk meningkatkan kualitas tenaga kerja dan peran sertanya dalam pembangunan serta peningkatan perlindungan tenaga kerja dan keluarganya sesuai dengan harkat dan martabat kemanusiaan;

d. Bahwa perlindungan terhadap tenaga kerja dimaksudkan untuk menjamin hak-hak dasar pekerja/buruh dan menjamin kesamaan kesempatan serta perlakuan tanpa diskriminasi atas dasar apa pun untuk mewujudkan kesejahteraan pekerja/buruh dan keluarganya dengan tetap memperhatikan perkembangan kemajuan dunia usaha; Bahwa tujuan dari di undangkannya Undang-Undang Nomor 13 Tahun 2003 tentang Ketenagakerjaan sangatlah berdampak positif, namun dalam penerapannya perlindungan dan jaminan kepastian hukum hak-hak buruh berpotensi terabaikan, mengingat putusan MK Nomor : 67/PUU-XI/2013 tersebut sangatlah jelas dan gamblang apabila hak upah pekerja haruslah didahulukan daripada kreditur-kreditur lainnya. Dalam pekera PT. Kertas Leces (persero) dinyatakan pailit dengan segala akibat hukumnya, serta mempunyai kekuatan hukum mengikat (inkracht van gewijs) hal demikian rupa terjadi lagi, hingga saat ini pembayaran upah para pemohon yaitu pekerja terkedala dan tidak terselesaikan.

Pembentukan peraturan perundang-undangan tidak lain adalah untuk mencapai sebuah keadilan secara individu maupun universal. Tidak sedikit orang beranggapan bahwa keadilan adalah sesuatu yang subyektif. Sesuatu yang hanya dapat di ukur melalui sudut pandang, paradigma, atau ideology yang dianut oleh pemutus keadilan. Oleh karena itu penulis melakukan penelitian hukum ini untuk sebisa mungkin membuka cakrawala pemikiran agar upaya yang musykil tersebut paling tidak sedikit demi sedikit dapat mewujudkan suatu keadilan yang berkepastian. 
Kepastian hukum secara normatif adalah ketika suatu peraturan dibuat dan diundangkan secara pasti karena mengatur secara jelas dan logis. Jelas dalam artian tidak menimbulkan keragu-raguan (multi-tafsir) dan logis. Jelas dalam artian ia menjadi suatu sistem norma dengan norma lain sehingga tidak berbenturan atau menimbulkan konflik norma. Kepastian hukum menunjuk kepada pemberlakuan hukum yang jelas, tetap, konsisten dan konsekuen yang pelaksanaannya tidak dapat dipengaruhi oleh keadaan-keadaan yang sifatnya subjektif. Kepastian dan keadilan bukanlah sekedar tuntutan moral, melainkan secara factual mencirikan hukum. Suatu hukum yang tidak pasti dan tidak bisa adil bukan sekedar hukum yang buruk.

Indonesia menganut sistem hubungan industrial yang berdasarkan Pancasila, yaitu suatu sistem yang didasarkan atas nilai-nilai yang merupakan manifestasi dari keseluruhan sila-sila Pancasila dan UUD 1945 yang tumbuh dan berkembang di atas kepribadian bangsa dan kebudayaan Nasional Indonesia. Dalam sistem ini, pemerintah dengan segenap upaya mendorong dan berperan serta untuk mendorong, melindungi dan memenuhi hak-hak buruh. Hal ini mengingat bahwa dalam praktik hubungan industrial, pekerja atau buruh dipandang sebagai salah satu faktor produksi di dalam perusahaan, dengan kata lain buruh/pekerja dianggap sebagai benda/barang yang merupakan objek dari hukum ekonomi yaitu hukum permintaan dan penawaran. Mengingat posisi hukum para pekerja yang rentan terabaikan, maka pemerintah membuat berbagai kebijakan yang menjamin dan melindungi hak-hak para pekerja, semisal melalui Undang-Undang Nomor 13 Tahun 2003 tentang Ketenagakerjaan, Undang-Undang Nomor 21 Tahun 2000 tentang Serikat Pekerja/Serikat Buruh, dan Undang-Undang Nomor 2 Tahun 2004 tentang Penyelesaian Perselisihan Hubungan Industrial. Dalam putusan pailit terhadap PT. Kertas Leces (persero) mempunyai kekuatan hukum mengikat (inkracht van gewijs), namun hingga saat ini pembayaran upah para pemohon yaitu pekerja terkendala dan tidak selesai, padahal secara norma hukum sudah sangatlah jelas dan gamblang.

\section{Kepastian Hukum Pemenuhan Upah Buruh Dalam Pembagian Harta Pailit Ditin- jau Dari Putusan Putusan Mahkamah Konstitusi Nomor 67/PUU-XI/2013.}

Istilah kepastian hukum dalam tataran teori tujuan hukum tidak memiliki pengertian yang baku. Hal ini disebabkan oleh banyaknya pendapat dari para ahli hukum yang berusaha menjelaskan arti dari istilah tersebut dengan argumen dan perspektif mereka masing-masing, baik dalam pengertian yang sempit maupun luas. Soerjono Soekanto mengemukakan pendapatnya tentang kepastian hukum: ${ }^{6}$

"Wujud kepastian hukum adalah peraturan-peraturan dari pemerintah pusat yang berlaku umum diseluruh wilayah negara. Kemungkinan lain adalah peraturan tersebut berlaku umum, tetapi bagi golongan tertentu, selain itu dapat pula peraturan setempat,

\footnotetext{
${ }^{6}$ Arifin P. Soeria Atmadja, Keuangan Publik dalam Perspektif Hukum, Teori, Praktik dan Kritik: Keuangan Negara Pasca perubahan UUD 1945, Jakarta, Rajawali Press, 2009, Hlm 128.
} 
yaitu peraturan yang dibuat oleh penguasa setempat yang hanya berlaku di daerahnya saja, misalnya peraturan kotapraja".

Hukum bertugas menciptakan kepastian hukum karena bertujuan untuk ketertiban masyarakat. Tanpa kepastian hukum, orang tidak tahu apa yang harus diperbuatnya sehingga akhirnya timbul keresahan. Tetapi jika terlalu menitik beratkan pada kepastian hukum dan ketat menaati peraturan hukum, maka akibatnya akan kaku serta menimbulkan rasa tidak adil. Adapun yang terjadi peraturannya tetap demikian, sehingga harus ditaati atau dilaksanakan. Undang-undang itu sering terasa kejam apabila dilaksanakan secara ketat, lex dure, sed tamen scripta (Undang-undang itu kejam, tapi memang demikianlah bunyinya). ${ }^{7}$ Kepastian adalah perihal (keadaan) yang pasti, ketentuan atau ketetapan. Hukum secara hakiki harus pasti dan adil. Pasti sebagai pedoman kelakukan dan adil karena pedoman kelakuan itu harus menunjang suatu tatanan yang dinilai wajar. Hanya karena bersifat adil dan dilaksanakan dengan pasti hukum dapat menjalankan fungsinya. Kepastian hukum merupakan pertanyaan yang hanya bisa dijawab secara normatif, bukan sosiologi. ${ }^{8}$

Menurut Kelsen, hukum adalah sebuah sistem norma. Norma adalah pernyataan yang menekankan aspek "seharusnya" atau das sollen, dengan menyertakan beberapa peraturan tentang apa yang harus dilakukan. Norma-norma adalah produk dan aksi manusia yang deliberatif. Undang-Undang yang berisi aturan-aturan yang bersifat umum menjadi pedoman bagi individu bertingkah laku dalam bermasyarakat, baik dalam hubungan dengan sesama individu maupun dalam hubungannya dengan masyarakat. Aturan-aturan itu menjadi batasan bagi masyarakat dalam membebani atau melakukan tindakan terhadap individu. Adanya aturan itu dan pelaksanaan aturan tersebut menimbulkan kepastian hukum. ${ }^{9}$ Kepastian hukum secara normatif adalah ketika suatu peraturan dibuat dan diundangkan secara pasti karena mengatur secara jelas dan logis. Jelas dalam artian tidak menimbulkan keragu-raguan (multi tafsir) dan logis. Jelas dalam artian ia menjadi suatu sistem norma dengan norma lain sehingga tidak berbenturan atau menimbulkan konflik norma. Kepastian hukum menunjuk kepada pemberlakuan hukum yang jelas, tetap, konsisten dan konsekuen yang pelaksanaannya tidak dapat dipengaruhi oleh keadaan-keadaan yang sifatnya subjektif. Kepastian dan keadilan bukanlah sekedar tuntutan moral, melainkan secara factual mencirikan hukum. Suatu hukum yang tidak pasti dan tidak mau adil bukan sekedar hukum yang buruk. ${ }^{10}$

Menurut Utrecht, kepastian hukum mengandung dua pengertian, yaitu pertama, adanya aturan yang bersifat umum membuat individu mengetahui perbuatan apa yang boleh atau tidak boleh dilakukan, dan kedua, berupa keamanan hukum bagi individu

\footnotetext{
${ }^{7}$ Sudikno Mertokusumo, Mengenal Hukum (Suatu Pengantar), Liberty, Yogyakarta, 1988, hlm. 136.

${ }^{8}$ Dominikus Rato, Filsafat Hukum Mencari: Memahami dan Memahami Hukum, Laksbang Pressindo, Yogyakarta, 2010, hlm.59

${ }^{9}$ Peter Mahmud Marzuki, Pengantar Ilmu Hukum, Kencana, Jakarta, 2008, hlm.158.

${ }^{10}$ Cst Kansil, Christine, S.T Kansil, Engelien R, Palandeng dan Godlieb N Mamahit, Kamus Istilah Hukum, Jakarta, 2009, Hlm. 385.
} 
dari kesewenangan pemerintah karena dengan adanya aturan yang bersifat umum itu individu dapat mengetahui apa saja yang boleh dibebankan atau dilakukan oleh Negara terhadap individu. ${ }^{11}$

Ajaran kepastian hukum ini berasal dari ajaran Yuridis-Dogmatik yang didasarkan pada aliran pemikiran positivistis di dunia hukum, yang cenderung melihat hukum sebagai sesuatu yang otonom, yang mandiri, karena bagi penganut pemikiran ini, hukum tak lain hanya kumpulan aturan. Bagi penganut aliran ini, tujuan hukum tidak lain dari sekedar menjamin terwujudnya kepastian hukum. Kepastian hukum itu diwujudkan oleh hukum dengan sifatnya yang hanya membuat suatu aturan hukum yang bersifat umum. Sifat umum dari aturan-aturan hukum membuktikan bahwa hukum tidak bertujuan untuk mewujudkan keadilan atau kemanfaatan, melainkan semata-mata untuk kepastian. ${ }^{12}$ Kepastian hukum merupakan jaminan mengenai hukum yang berisi keadilan. Norma-norma yang memajukan keadilan harus sungguh-sungguh berfungsi sebagi peraturan yang ditaati.

Menurut Gustav Radbruch keadilan dan kepastian hukum merupakan bagian-bagian yang tetap dari hukum. Beliau berpendapat bahwa keadilan dan kepastian hukum harus diperhatikan, kepastian hukum harus dijaga demi keamanan dan ketertiban suatu negara. Akhirnya hukum positif harus selalu ditaati. Berdasarkan teori kepastian hukum dan nilai yang ingin dicapai yaitu nilai keadilan dan kebahagiaan.

Berkaitan dengan pembahasan sebelumnya dalam penelitian ini, penulis akan memaparkan tentang istilah "pailit" yang penulis dijumpai didalam perbendaharaan bahasa Belanda, Perancis, Latin dan Inggris dengan istilah yang berbeda-beda. Di dalam bahasa Perancis istilah "faillite" artinya pemogokan atau kemacetan dalam melakukan pembayaran. Oleh sebab itu orang mogok atau macet atau berhenti membayar utangnya di dalam bahasa Perancis disebut lefailli. Untuk arti yang sama di dalam bahasa Belanda dipergunakan istilah failliet. Sementara itu dalam undang-undang kepailitan yang baru, pasal 1 ayat (1) Undang-undang nomor 37 tahun 2004 tentang Kepailitan dan Penundaan Kewajiban Pembayaran Utang (UUKPKPU) berbunyi : ${ }^{13}$

"Kepailitan adalah sita umum atas semua kekayaan debitor pailit yang pengurusan dan pemberesannya dilakukan oleh kurator di bawah pengawasan hakim sebagaimana diatur dalam undang-undang ini".

Menurut Retnowulan, dalam bukunya Kapita Selekta Hukum Ekonomi dan Perbankan, seri varia yustisia, yang dimaksud dengan kepailitan adalah eksekusi masal yang ditetapkan dengan keputusan hakim, yang berlaku serta merta, dengan melakukan penyitaan umum atas semua harta orang yang dinyatakan pailit, baik yang ada pada

\footnotetext{
${ }^{11}$ Riduan Syahrani, Rangkuman Intisari Mmu Hukum, Penerbit Citra Aditya Bakti,Bandung, 1999, hlm.23.

${ }^{12}$ Achmad Ali, Menguak Tabir Hukum (Suatu Kajian Filosofis dan Sosiologis), Penerbit Toko Gunung Agung, Jakarta, 2002, hlm. 82-83.

${ }^{13}$ pasal 1 angka 1 undang-undang nomor 37 tahun 2004 tentang Kepailitan dan Penundaan Kewajiban Pembayaran Utang.
} 
waktu pernyataan pailit, maupun yang diperoleh selama kepailitan berlangsung, untuk kepentingan semua kreditur, yang melakukan dengan pengawasan pihak berwajib. Dari pengertian pailit tersebut diatas, dapat disimpulkan bahwa:

a. Kepailitan dimaksudkan untuk mencegah penyitaan dan eksekusi yang dimintakan oleh kreditur secara perorangan.

b. Kepailitan hanya mengenai hartabbenda debitur, bukan pribadinya.Jadi, ia tetap cakap dalam melakukan perbuatan hukum diluar hukum kekayaan.

Maka secara sederhana, kepailitan dapat diartikan sebagai suatu penyitaan semua asset debitur yang dimasukan dalam permohonan pailit. Debitur tidak serta merta kehilangan untuk melakukan tindakan hukum, akan tetapi kehilangan untuk mengurus dan menguasai harta kekayaannyayang dimasukan didalam kepailitan terhitung sejak pernyataan pailit tersebut. ${ }^{14}$ Sitaan terhadap seluruh harta kekayaan debitur disebut pula sebagai eksekusi kolektif (collective execution). Suatu proses khusus dari eksekusi kolektif dilakukan secara langsung terhadap semua kekayaan yang dimiliki oleh debitur oleh untuk manfaat semua kreditur.

Syarat agar debitur dapat dinyatakan Pailit, menurut Pasal 1 Undang-Undang Nomor 37 Tahun 2004 tentang Kepailitan dan Penundaan Kewajiban Pembayaran Utang, yaitu: a. Debitur memiliki dua atau lebih kreditur.

b. Debitur tidak membayar sedikitnya satu utang yang telah jatuh waktu atau dapat ditagih.

c. Atas permohonannya sendiri maupun atas permintaan seorang ataulebih krediturnya. Pernyataan pailit diperiksa secara sederhana (sumir), ialah bila dalam mengambil keputusan tidak diperlukan alat-alat pembuktian seperti diatur dalam buku ke IV KUH Perdata cukup bila pertistiwa itu telah terbukti dengan alat-alat pembuktian yang sederhana. Tentang syarat untuk pailit dalam UUK No.4 Tahun 1998 diatur dalam pasal 1 dan dalam UUK No.37 Tahun 2004 diatur dalam pasal 2 ayat (1), pada prinsipnya keduanya mengatur hal yang sama, hanya beda penempatan pasal saja. Lahirnya pasal ini sebenarnya dalam rangka untuk lebih memberikan perlindungan hukum kepada kreditur atau para kretditur dibandingkan ketentuan kepailitan yang lama (pasal 1) yang mana terdapat celah hukum yang sering kali dimanfaatkan oleh debitur yang nakal, karena didalam pasal 1 peraturan kepailitan (yang lama) syaratnya hanya debitur dalam keadaan berhenti membayar, tanpa ada penjelasan lebih lanjut maka kemudian disalah artikan, mestinya untuk debitur yang benar-benar tidak mampu membayar bukan debitur yang tidak mau membayar kemudian meminta dijatuhi kepailitan. Pihak-Pihak yang dapat mengajukan Permohonan Kepailitan, apabila dilihat pada ketentuan pasal 1 undang-undang nomor 37 tahun 2004 tentang kepailitan dan Penundaan Kewajiban Pembayaran Utang, adalah:

a. Debitur sendiri yang memiliki dua atau lebih kreditur.

\footnotetext{
${ }^{14}$ Rahayu Hartini, Hukum Kepailitan, Malang, UMM Press, 2017, hlm 20.
} 
b. Seorang kreditur atau lebih, baik secara sendiri-sendiri maupun bersama-sama.

c. Jaksa Penuntut Umum

d. Bank Indonesia

e. Badan Pengawas Pasar Modal - Otoritas Jasa Keuangan

f. Menteri Keuangan

Jika dikaitkan teori kepastian hukum dengan hukum kepailitan dan Penundaan Kewajiban Pembayaran Utang (UUKPKPU) pasal 1 undang-undang nomor 37 tahun 2004 mengenai Hak buruh dalam tata urutan pembagian harta pailit, maka kewajiban Debitur untuk membayar utang dan kreditur mendapatkan Hak pembayaran tersebut adalah sebuah kewajiban yang mutlak harus dipenuhi. Oleh karena hal tersebut dari sekian banyak perusahaan BUMN Persero hanya PT. Kertas Leces yang berujung dengan keputusan pailit yang mempunyai kekuatan hukum tetap (incracht), sedangkan didalam undang-undang kepailitan mengenai ketentuan tata urutan pembagian harta pailit masih mengalami beberapa kerancuan atau tumpang tindih peraturan terkait krditur mana yang harus di dahulukan, meskipun dalam Putusan Mahkamah Konstitusi 67/PUU-XI/2013 telah jelas menyatakan bahwa Upah buruh didahulukan, namun kreditur separatis lainnya menyataklan dirinyalah yang harus didahulukan berdasarkan ketentuan undang-undang mengatur, Penulis juga menemukan terdapat beberapa kerancuan peraturan perundang-undangan yang mengatur tata urutan pembagian harta pailit terhadap klasifikasi kreditur, baik Preferen, Separatis maupun Konkuren, karena Kreditur Preferen mempunyai hak istimewa untuk didahulukan pembayaraan karena undang-undang, sedangkan Kreditur Separatis mempunyai hak juga menurut undangundang untuk didahulukan karena memegang hak jaminan yang dapat sewaktu-waktu melakukan parate eksekusi. Lantas yang menjadi focus kajian dan analisa hukum penulis adalah apakah upah buruh masuk dalam klasifikasi Kreditur Preferen (namun harus didahulukan daripada hak Negara), atau Kreditur Separatis (yang memegang hak jaminan) atau kreditur lainnya, karena apabila masuk dalam kategori Kreditur Preferen mana yang harus didahulukan, upah buruh atau pajak?, mengingat Putusan Mahkamah Konstitusi Nomor 67/PUU-XI/2013 yang pada pokoknya menyatakan pembayaran upah buruh didahulukan daripada kreditur lainnya, namun para kreditur lain seperti separatis dan preferen juga menyatakan haknya harus didahulukan karena mempunyai Hak untuk mendahului sebagaimana di atur dalam undang-undang Perpajakan, Jaminan Kebendaan, Fidusia, dan Hak Tanggungan. Akan tetapi dalam perkara PT. Kertas Leces tersebut mantan buruh ditempatkan dalam posisi setelah pemenuhan hak negara dan para kreditor separatis, menimbulkan adanya ketidakpastian hukum apabila mengacu Putusan Mahkamah Konstitusi Nomor 67/PUU-XI/2013 yang amarnya sebagai berikut:

"Pasal 95 ayat (4) Undang-Undang Nomor 13 Tahun 2003 tentang Ketenagakerjaan (Lembaran Negara Republik Indonesia Tahun 2003 Nomor 39, Tambahan Lembaran Negara Republik Indonesia Nomor 4279) bertentangan dengan Undang-Undang Dasar 
Negara Republik Indonesia Tahun 1945 sepanjang tidak dimaknai: "pembayaran upah pekerja/buruh yang terhutang didahulukan atas semua jenis kreditur termasuk atas tagihan kreditur separatis, tagihan hak negara, kantor lelang, dan badan umum yang dibentuk Pemerintah, sedangkan pembayaran hak-hak pekerja/buruh lainnya didahulukan atas semua tagihan termasuk tagihan hak negara, kantor lelang, dan badan umum yang dibentuk Pemerintah, kecuali tagihan dari kreditur separatis".

Hal inilah yang menjadi sebuah ketidakpastian hukum dan tidak tepat dalam penerapannya, padahal Hak-Hak buruh didalamnya yang harus dipenuhi, kemana peran pemerintah dalam hal ini. Pada kasus ini manakah yang seharusnya menjadi prioritas, kepentingan manusia terhadap properti atau kepentingan manusia terhadap diri dan kehidupannya. Apalagi berdasarkan sistem pembayaran upah pekerja/buruh dalam kegiatan usaha yang dibayar sebulan setelah pekerja melaksanakan pekerjaan, hal ini merupakan argumentasi tersendiri karena upah pekerja/buruh sesungguhnya adalah hutang pengusaha kepada pekerja/buruh, yang seharusnya harus dibayar sebelum kering keringatnya.

Prinsip-prinsip hukum merupakan ratio-legis dari suatu norma hukum. Prinsip merupakan jantung dari suatu aturan hukum, dan ia merupakan landasan yang paling luas apabila terjadi kekaburan suatu peraturan hukum. Bahwa suatu peraturan hukum tidak akan ada tanpa didasari oleh adanya suatu prinsip yang pada hakikatnya tetap bermuara apabila terjadi suatu ketidakpastian hukum suatu peraturan. Bahwa prinsip hukum tidaklah akan habis kekuatannya, yang selanjutnya akan hidup, tumbuh, dan berkembang karena prinsip mengandung nilai-nilai tuntunan etis kehidupan.

\section{SIMPULAN}

Suatu aturan hukum harus bercermin terhadap suatu prinsip dan nilai-nilai etis, tidak dapat suatu aturan hukum menghalang-halangi suatu hak yang seharusnya seseorang dapatkan dengan utuh dan tanpa pengecualian. Pada sejatinya buruh adalah orang yang dibayar karena suatu pekerjaan yang dilakukannya, bukan diklasifikasikan sebagai seorang kreditur, maka sepatutnyalah apabila buruh didahulukan dalam pembagian harta pailit dan mengecualikan dari status kreditur.

\section{DAFTAR PUSTAKA}

\section{Buku}

Achmad Ali, (2002), Menguak Tabir Hukum (Suatu Kajian Filosofis dan Sosiologis), Penerbit Toko Gunung Agung, Jakarta.

Arifin P. Soeria Atmadja, (2009), Keuangan Publik dalam Perspektif Hukum, Teori, Praktik dan Kritik: Keuangan Negara Pasca perubahan UUD 1945, Rajawali Press, Jakarta.

Cst Kansil, Christine, S.T Kansil, Engelien R, Palandeng dan Godlieb N Mamahit, 
(2009), Kamus Istilah Hukum, Jakarta.

Dominikus Rato, (2010), Filsafat Hukum Mencari: Memahami dan Memahami Hukum, Laksbang Pressindo, Yogyakarta.

Peter Mahmud Marzuki, (2008), Pengantar Ilmu Hukum, Kencana, Jakarta.

Riduan Syahrani, (1999), Rangkuman Intisari Ilmu Hukum, Penerbit Citra Aditya Bakti, Bandung.

Rahayu Hartini, (2017), BUMN PERSERO, Konsep Keuangan Negara dan Hukum Kepailitan Di Indonesia”, Setara Press, Malang.

Rahayu Hartini, (2017), Hukum Kepailitan, UMM Press, Malang.

Soerjono Soekanto, (1974), Beberapa Permasalahan Hukum Dalam Kerangka Pembangunan Indonesia, UI Pres, Jakarta.

Sudikno Mertokusumo, (1988), Mengenal Hukum (Suatu Pengantar), Liberty, Yogyakarta.

Sudikno Mertukusumo, (2009), Penemuan Hukum, Liberty, Yogyakarta.

\section{Jurnal}

Sidabutar, L. M. J. (2019). Hukum Kepailitan Dalam Eksekusi Harta Benda Korporasi Sebagai Pembayaran Uang Pengganti. Integritas: Jurnal Antikorupsi, 5(2), 7586.

Rahmani, I. (2018). Perlindungan Hukum Kepada Pembeli Dalam Kepailitan Pengembang (Developer) Rumah Susun. Jurnal Hukum Bisnis Bonum Commune, 1(1), 7388.

Hamdi, H., \& Afrizal, T. Y. (2020). Perlindungan Hukum Bagi Kreditor Terhadap Pelunasan Piutang Dari Harta Pailit. Jurnal Ilmiah Mahasiswa Fakultas Hukum, 1(1).

Hartono, D. T. (2016). Perlindungan Hukum Kreditor Berdasarkan Undang-Undang Kepailitan (Doctoral dissertation, Tadulako University). 